\title{
Anti-inflammatory and antiproliferative activities of Ixora brevifolia Benth. (Rubiaceae)
}

Rebeca P. Medina, Vagner M. de Moura, Cleuza C. da Silva, Cecília M. A. de Oliveira, Lucilia Kato, Armando M. Pomini, João E. de Carvalho, Ana Lúcia T. G. Ruiz, Ciomar A. Bersani-Amado \& Silvana M. O. Santin

To cite this article: Rebeca P. Medina, Vagner M. de Moura, Cleuza C. da Silva, Cecília M. A. de Oliveira, Lucilia Kato, Armando M. Pomini, João E. de Carvalho, Ana Lúcia T. G. Ruiz, Ciomar A. Bersani-Amado \& Silvana M. O. Santin (2018) Anti-inflammatory and antiproliferative activities of Ixora brevifolia Benth. (Rubiaceae), Natural Product Research, 32:11, 1357-1360, DOI: 10.1080/14786419.2017.1344654

To link to this article: https://doi.org/10.1080/14786419.2017.1344654

View supplementary material ¿

Published online: 23 Jun 2017.

Submit your article to this journal

Џll Article views: 85

View Crossmark data $₫$ 


\section{Anti-inflammatory and antiproliferative activities of Ixora brevifolia Benth. (Rubiaceae)}

Rebeca P. Medina ${ }^{a}$, Vagner M. de Moura ${ }^{a}$, Cleuza C. da Silva ${ }^{a}$, Cecília M. A. de Oliveirab, Lucilia Katob ${ }^{\text {, Armando M. Pominia }}$, João E. de Carvalhoc, Ana Lúcia T. G. Ruizc, Ciomar A. Bersani-Amado ${ }^{d}$ and Silvana M. O. Santin ${ }^{a}$

aDepartamento de Química, Universidade Estadual de Maringá, Maringá, Paraná, Brazil; ' Instituto de Química, Universidade Federal de Goiás, Goiânia, Brazil; 'Centro Pluridisciplinar de Pesquisa Químicas, Biológicas e Agrícolas, Universidade Estadual de Campinas, Campinas, Brazil; ${ }^{d}$ Departamento de Farmacologia, Universidade Estadual de Maringá, Maringá, Brazil

\section{ABSTRACT}

The crude extract and fractions from the branches of Ixora brevifolia, a tree found in the Brazilian Cerrado, were tested for anti-inflammatory and in vitro antiproliferative effects. The crude extract and $n$-hexane fraction exhibited significant inhibition of ear oedema in mice, while $n$-hexane-precipitated and chloroform fractions strongly inhibited the myeloperoxidase activity in ear tissue. The $n$-hexane and $n$-hexaneprecipitated fractions showed strong growth inhibition for glioma cell line and the hydromethanolic fraction inhibited the growth of leukaemia cell line.
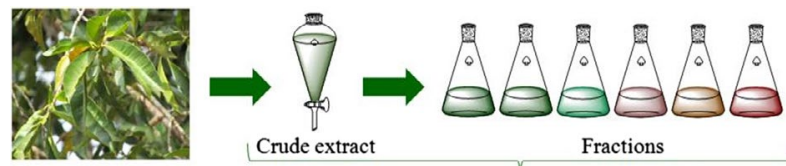

Crude extract

Branches of Ixora brevifolia

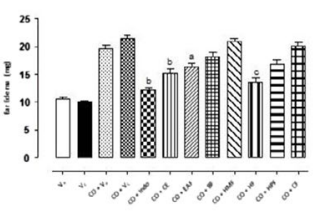

Anti-inflammatory activity
Fractions

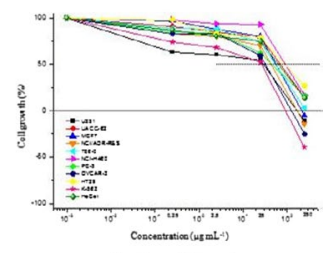

Antiproliferative activity

\section{ARTICLE HISTORY}

Received 9 November 2016

Accepted 1 June 2017

\section{KEYWORDS}

Ixora brevifolia; Rubiaceae; antiproliferative activity; anti-inflammatory activity

\section{Introduction}

Ixora is a genus of ca. 400 species; several are used in traditional medicine for treatment of diarrhoea, fever, headaches, ulcers and cancer (Nair \& Panikkar 1990; Chen, Zhang et al.

CONTACT Silvana M. O. Santin smoliveira@uem.br

${ }^{\S}$ Núcleo de Bioensaios, Biossíntese e Ecofisiologia de Produtos Naturais (NuBBE), Departamento de Química Orgânica, Instituto de Química, UNESP - Univ. Estadual Paulista, 14801-970, Araraquara-SP, Brazil.

(4) Supplemental data for this article can be accessed at https://doi.org/10.1080/14786419.2017.1344654. 
2016). Previous phytochemical and biological studies of species from Ixora genus and their isolated compounds showed the presence of phenols, terpenoids and peptides (Lee et al. 2010; Chen, Zhan, et al. 2016; Ikram et al. 2016) and a variety of activities are related to traditional uses (Chen, Zhang et al. 2016).

Ixora brevifolia Benth. is a tree found in Brazilian Cerrado and popularly known as 'ixora-arborea'. One of our previous studies, carried out with the branches of this species, described the isolation and identification of a new cyclopeptide alkaloid, named ixorine, along with five known compounds, frangulanine, cinnamtannin B-1, syringaresinol, daucosterol and mannitol. The study also reported the activity of two cyclopeptide alkaloids mixture against Leishmania amazonensis (Medina et al. 2016).

The present work describes the anti-inflammatory and antiproliferative potential of methanol crude extract and fractions from the branches of Ixora brevifolia.

\section{Results and discussion}

To evaluate the anti-inflammatory activity, croton oil was used to induce the local inflammatory process, characterised by an oedema formation and increased activity of myeloperoxidase (MPO) in the injured tissue. The results of anti-inflammatory activity assays are expressed as percentage of inhibition of ear oedema (weight) and MPO activity (absorbance) (Figures S1 and S2, Table S1).

The crude extract (CE) showed moderate inhibition of ear oedema $(49.4 \%, p<0.001)$ and the $n$-hexane fraction (HF) caused a high inhibition $(68.8 \%, p<0.001)$. In addition, the $\mathbf{H F}$, $n$-hexane precipitated (HPF, obtained from HF) and chloroform (CF) fractions were effective in inhibiting the MPO activity $(57.9 \%, p<0.001 ; 81.5 \%, p<0.001$ and $76.4 \%, p<0.001$, respectively). MPO is a heme-enzyme used as a marker of migration of polymorphonuclear cells related to inflammation response. An inhibition of its activity could indicate that the main anti-inflammatory mechanism of these fractions is related to the inhibition of migration of polymorphonuclear cells.

The in vitro antiproliferative activity of the crude extract and fractions was evaluated using 10 different human cancer cell lines and a non-tumoural cell line. The results are expressed as the concentration that produced $50 \%$ of cell growth inhibition $\left(\mathrm{Gl}_{50}, \mu \mathrm{g} \mathrm{mL}^{-1}\right)$ for each cell line (Table S2).

The CE exhibited antiproliferative activity against all tumour cell lines and presented marked inhibitory effect on the growth of glioma (U251, $\mathrm{Gl}_{50}=26.8 \mu \mathrm{g} \mathrm{mL}^{-1}$ ) and leukaemia $\left(\mathrm{K} 562, \mathrm{Gl}_{50}=28.0 \mu \mathrm{g} \mathrm{mL}^{-1}\right)$ cell lines. The $\mathbf{H F}$ and HPF fractions showed significant selectivity and potent antiproliferative activity for the glioma cell line (U251, $\mathrm{Gl}_{50}=4.1$ and $1.5 \mu \mathrm{g} \mathrm{mL}^{-1}$, respectively). The HPF fraction also inhibited the growth of ovary (OVCAR-3, $\mathrm{Gl}_{50}=10.1 \mu \mathrm{g} \mathrm{mL}^{-1}$ ) and leukaemia $\left(\mathrm{K} 62, \mathrm{Gl}_{50}=19.6 \mu \mathrm{g} \mathrm{mL}^{-1}\right)$ cell lines. The $\mathbf{C F}$ fraction exhibited antiproliferative activity against all tumour cell lines, with $\mathrm{Gl}_{50}$ values in the range 25.5-81.8 $\mu \mathrm{g} \mathrm{mL} \mathrm{m}^{-1}$. The hydromethanolic (HMF) and butanolic (BF) fractions presented selectivity against leukaemia cell line with high and moderate growth inhibition $\left(\mathrm{K} 562, \mathrm{Gl}_{50}=4.6\right.$ and $25.2 \mu \mathrm{g} \mathrm{mL} \mathrm{m}^{-1}$, respectively).

Finally, previous phytochemical work described the isolation of some bioactive compounds: lignan syringaresinol and cyclopeptide alkaloids ixorine and frangulanine from CF; and daucosterol from HF and HF (Medina et al. 2016) (Figure S11). The cyclopeptide alkaloids ixorine and frangulanine have never been described as antiproliferative or anti-inflammatory 
agents. However, the peptides isolated from I. coccinea, ixorapeptide I and ixorapeptide II, exhibited selective potential against Hep3B liver cancer cell line and significant anti-inflammatory effects on neutrophils, respectively (Lee et al. 2010). Syringaresinol possesses strong cytotoxic activity against hepatocarcinoma cell line HepG2, high anti-inflammatory activity as indicated by inhibited LPS-induced NO generation and presents strong scavenging activity against DPPH (El-Desouky \& Gamal-Eldeen 2009). Daucosterol has been described as inhibiting the growth of human colon cancer cell line HCT-116 (Wang et al. 2016), and to present anti-inflammatory activity in lipopolysaccharide-stimulated RAW 264.7 murine macrophages (Choi et al. 2012). Therefore, the presence of these metabolites could explain the positive results presented by $\mathbf{C F}, \mathbf{H F}$ and $\mathbf{H P F}$ in anti-inflammatory and in vitro antiproliferative assays.

\section{Conclusion}

This is the first evaluation of biological activities of the plant I. brevifolia. Our study demonstrates the antiproliferative and anti-inflammatory properties of this species, and the results corroborate the pharmacological properties observed for other members of the Ixora genus, which could be attributed to the similar compounds or the same active metabolites being present in this species.

\section{Supplementary material}

Experimental details, Tables S1 and S2 and other data are available online.

\section{Disclosure statement}

No potential conflict of interest was reported by the authors.

\section{Funding}

We acknowledge the Coordenação de Aperfeiçoamento de Nível Superior (CAPES) for fellowship (R. P. M.) and financial support.

\section{References}

Chen L, Zhan R, Jiang J, Zhang Y, Dong Y, Chen Y. 2016. A new ent -kaurane diterpenoid from Ixora amplexicaulis. Nat Prod Res. 30:105-109.

Chen L, Zhang Y, Chen Y. 2016. Chemical constituents of plants from the genus Ixora. Chem Biodivers. 13:275-283.

Choi JN, Choi Y-H, Lee J-M, Noh IC, Park JW, Choi WS, Choi JH. 2012. Anti-inflammatory effects of $\beta$-sitosterol- $\beta$ - D -glucoside from Trachelospermum jasminoides (Apocynaceae) in lipopolysaccharidestimulated RAW 264.7 murine macrophages. Nat Prod Res. 26:2340-2343.

El-Desouky SK, Gamal-Eldeen AM. 2009. Cytotoxic and anti-inflammatory activities of some constituents from the floral buds of Syringa patula. Pharm Biol. 47:872-877.

Ikram A, Versiani MA, Khatoon A, Ahmed SK, Sattar SA, Faizi S. 2016. New dammarane and ursane-type triterpenoids from the flower of Ixora coccinea Linn. Nat Prod Res. 30:768-775.

Lee CL, Liao YC, Hwang TL, Wu CC, Chang FR, Wu YC. 2010. Ixorapeptide I and ixorapeptide II, bioactive peptides isolated from Ixora coccinea. Bioorganic Med Chem Lett. 20:7354-7357. 
Medina RP, Schuquel ITA, Pomini AM, Silva CC, Oliveira CMA, Kato L, Nakamura CV, Santin SMO. 2016. Ixorine, a new cyclopeptide alkaloid from the branches of Ixora brevifolia. J Braz Chem Soc. 27:753758.

Nair SC, Panikkar KR. 1990. Antitumour principles from Ixora javanica. Cancer Lett. 49:121-126.

Wang G-Q, Gu J-F, Gao Y-C, Dai Y-J. 2016. Daucosterol inhibits colon cancer growth by inducing apoptosis, inhibiting cell migration and invasion and targeting caspase signalling pathway. Bangladesh J Pharmacol. 11:395-401. 